\title{
Effects of Exogenous Glucoamylase Enzymes Alone or in Combination with a Neutral Protease on Apparent Total Tract Digestibility and Feces $D$-Lactate in Crossbred Angus Bulls Fed a Ration Rich in Rolled Corn
}

\author{
Maria Devant ${ }^{1, *}$, Shukun Yu ${ }^{2}$, Sandra Genís ${ }^{1,3}$, Torben Larsen ${ }^{4}$ and Li Wenting 5 \\ 1 Ruminant production, IRTA, Torre Marimon, 08140 Caldes de Montbui, Spain; sandra.genis@gmail.com \\ 2 DuPont Nutrition \& Biosciences, Edwin Rahrs Vej 38, 8220 Brabrand, Denmark; Shukun.Yu@dupont.com \\ BonÀrea Agrupa, Traspalau 8, 25210 Guissona, Spain \\ 4 Department of Animal Science, Blichers Allé 20, 8830 Tjele, Denmark; torben.larsen@anis.au.dk \\ 5 DuPont Nutrition \& Biosciences, Wilmington, DE 19803, USA; WENTING.LI@dupont.com \\ * Correspondence: maria.devant@irta.cat
}

Received: 1 May 2020; Accepted: 15 June 2020; Published: 23 June 2020

check for

Simple Summary: Dietary enzyme supplementation, as a feed additive, has been well adopted in monogastric production to increase feed efficiency. However, in ruminants, considerably fewer studies have been done and fewer, if any, commercial enzymes have been adopted as a feeding strategy. Feedlot cattle are commonly fed high-starch diets, with varying starch digestibilities depending on type of grain, and degree of grain processing. Improvement in starch digestibility in low processed grain diets will undoubtedly warrant economic benefits to feedlot producers and reduce environmental impact of intensive beef production. In this study, we have shown that dietary glucoamylase supplementation improved 7 to $13 \%$ apparent digestibility of dry matter and starch in bulls fed rolled corn-based diets, suggesting that enzyme (glucoamylase) supplementation could be a promising strategy to improve starch efficiency for finishing beef cattle.

\begin{abstract}
The aim of this study was to evaluate the effect of two glucoamylases (GA) and the combination of one GA with a neutral protease on apparent total tract digestibility in beef bulls fed a total mixed ration (TMR) rich in rolled corn. Sixteen Angus beef bulls ( $266 \pm 4.9 \mathrm{~kg}$ of initial BW, and $182 \pm 1.7 \mathrm{~d}$ of age) were distributed in 4 blocks, each block consisted of 4 animals balanced by BW. The experimental design was a $4 \times 4$ Latin square ( 4 blocks and 4 periods, $2 \mathrm{w}$ per period). Four treatments were tested; (1) control, (2) GA preparation from Trichoderma reesei (TrGA); (3) GA from Aspergillus fumigatus (AfuGA); (4) AfuGA in combination with a neutral protease from Bacillus amyloliquefaciens (BamPro). Apparent total tract digestibility and fecal $D$-lactate concentration were analyzed. Enzyme supplementation, regardless of enzyme type, increased apparent total tract digestibility of dry matter (from $66.7 \%$ to $73.1 \% \pm 2.01$ ), and starch (from $74.7 \%$ to $81.8 \% \pm 2.25$ ), without affecting feces $D$-lactate concentration. Irrespective of glucoamylase type, glucoamylase supplementation improved apparent digestibility of dry matter and starch, and the addition of a protease did not have additional benefits on nutrient digestibility.
\end{abstract}

Keywords: beef; feed; glucoamylase; protease; total tract digestibility; fecal $D$-lactate 


\section{Introduction}

Energy intake and digestibility, particularly the energy obtained from starch, is the limiting factor for growth in feedlot beef cattle [1]. Corn is the predominant grain (dry rolled, ground, high moisture or steam flaked) and starch source used in the US, Central and Latin America feedlots [2]. Among the grain processing methods, steam flaking is an effective way to increase starch availability for ruminants. Studies have shown that feeding steam flaked corn in finishing cattle increased ruminal and total tract starch digestibility about 10 to $20 \%$ and 7 to $10 \%$, respectively, compared with dry rolled corn $[3,4]$. However, steam flaking is a process that requires large capital investment, and thus might be cost prohibitive for small farms. Therefore, alternative methods to enhance the starch availability for dry rolled corn will be beneficial to producers, especially when access to steam flakers is limited. Unfortunately, given the amount of research done on enzyme application in ruminants, industry-wise adoption of exogenous enzyme is still very low, partly due to inconsistent results. In addition, the majority of the enzyme application studies were done with fiber-degrading enzymes, such as xylanase, and information on starch degrading enzyme is sparse. The present study is one of the first studies where glucoamylases (GA) from glycoside hydrolase family 15 (GH15) (EC 3.2.1.3) are tested in cattle. The end product of these GA enzymes is glucose instead of the mixture of glucose, maltose and maltooligosaccharides which are the end products produced by $\alpha$-amylase (AA) (GH13) (EC 3.2.1.1). Based on the abundance of genes, coding for the enzymes in the rumen [5,6] AA activity is much greater compared with GA. Therefore, it is hypothesized that supplementing ruminally active GA will complement AA activity and enhance starch degradation as a result. With that, the current study evaluated the efficacy of two GAs, TrGA (from Trichoderma reesei) and AfuGA (AfuGA from Aspergillus fumigatus) in beef cattle fed corn-based, high concentrate finishing diet. Both enzymes were active in the rumen and highly specific to maltose, as observed in previous in vitro studies [7]. In addition, a neutral protease (BamPro from Bacillus amyloliquefaciens; [8]) stable at rumen $\mathrm{pH}$ (from 5.5 to 7) was included as a third treatment and supplemented in combination with AfuGA (AfuGA+BamPro), hypothesizing that the combination would synergistically increase starch digestibility with GA by degrading the protein matrix encasing starch granule in the endosperm [9]. Therefore, the novelty in the present study is that, as mentioned previously, it differs from most previously published studies where fungal and bacterial AA and bacterial serine protease have been evaluated [10,11]. Finally, decreased $D$-lactate concentrations in feces could be an indicator of improved overall starch digestion in the digestive tract, since $D$-lactate is of microbial origin and not produced by mammalian cells [12]. The objective of the present study was to evaluate the effect of two exogenous GA enzymes, alone or in combination, with a neutral metalloprotease on apparent total tract digestibility and on fecal $D$-lactate concentration in crossbred Angus bulls fed a high rolled corn-based diet.

\section{Materials and Methods}

\subsection{Animals, Housing, Experimental Design and Diets}

All experimental protocols were approved by the Institutional Animal Care Committee of the Institut de Recerca i Tecnologia Agroalimentàries (Barcelona, Spain, number FUE-2018-00702882- 9970), and the study was conducted in accordance with the Spanish guidelines for experimental animal protection [13].

Sixteen Angus beef bulls ( $266 \pm 4.9 \mathrm{~kg}$ of initial BW, and $182 \pm 1.7 \mathrm{~d}$ of age) were allocated in individual, partially slatted pens $(1.9 \times 3.4 \mathrm{~m})$ at the experimental station of the Cooperativa Agraria de Guissona (Guissona, Lleida, Spain). Before starting the study, all animals were adapted to the experimental total mixed ration (TMR); from -14 to -11 day all animals were fed with concentrate (32.9\% rolled corn, $11.5 \%$ wheat middlings, $10.0 \%$ hominy feed, $9.5 \%$ barley, $8.0 \%$ corn dried distilled grains, $10.0 \%$ soybean meal, $7.0 \%$ wheat, $3.0 \%$ sunflower meal, $1.5 \%$ beet pulp, $1.0 \%$ palm oil, $3.46 \%$ vitamin-mineral premix, $1.77 \%$ calcium carbonate, $0.37 \%$ salt, $3.25 \mathrm{Mcal} / \mathrm{kg} \mathrm{ME}, 16.5 \%$ Crude Protein (CP), $5.6 \%$ ether extract, $17.2 \%$ NDF and $5.9 \%$ ash) and long straw (3.5\% CP, $1.6 \%$ ether extract, 
70.9\% NDF, and 6.1\% ash; DM basis), both ad libitum, in two separate feeders $(0.6 \times 1.2 \times 0.3 \mathrm{~m})$. From -10 to -6 day animals were fed with concentrate and long straw in two separate feeders $(0.6 \times$ $1.2 \times 0.3 \mathrm{~m}$ ), and TMR (see Table 1$)$, in a separate feeder $(0.6 \times 1.2 \times 0.3 \mathrm{~m})$, free of choice and ad libitum; from -5 to day 0 all animals were fed TMR only ad libitum. The TMR was the same in all treatments and was formulated according to NRC [14] recommendations. During the study, the TMR was fed in one trough $(0.6 \times 1.2 \times 0.3 \mathrm{~m})$ and all animals were fed ad libitum. The pens were also equipped with a water bowl drinker.

Animals were assigned to one of the four blocks, each block had 4 animals, and blocks were balanced by animal BW. The experiment was designed as a $4 \times 4$ Latin Square with blocks and periods of $2 \mathrm{w}$. The total study length was of $8 \mathrm{w}$. Each block in the first period was randomly assigned to 1 of 4 treatments. The four tested treatments were: Treatment 1 (CTR) was blank solution where the solution was mixed with the total mixed ration (TMR) at a rate of $10 \mathrm{~mL}$ for $40 \mathrm{~kg}$ TMR. The blank solution contained $0.2 \%$ potassium sorbate and $0.6 \%$ sodium benzoate that corresponded to the preservatives used in the liquid enzyme preparations; Treatment 2 was a GA preparation from the fungus T. reesei (TrGA); Treatment 3 was a GA preparation from A. fumigatus (AfuGA); Treatment 4 (AfuGA+BamPro) was AfuGA and a B. amyloliquefaciens neutral protease (EC 3.4.24.28) preparation (BamPro). TrGA and AfuGA were dosed at 150 and 100 glucoamylase units per $\mathrm{kg}$ TMR, respectively, measured by using 4-nitrophenyl- $\alpha$-D-glucopyranoside as substrate at $\mathrm{pH} 4.3$ and $30{ }^{\circ} \mathrm{C}$. The dose for the protease was 39,100 protease units/kg TMR. All the enzymes were mixed with the same blank solution as CTR and were provided by DuPont Nutrition \& Biosciences Aps (Brabrand, Denmark). Enzyme preparations were kept at $4{ }^{\circ} \mathrm{C}$ and were mixed daily with the TMR $15 \mathrm{~min}$ before animals were fed.

Table 1. Ingredient and nutrient composition of total mixed ration (TMR).

\begin{tabular}{cc}
\hline Item & \\
\hline Ingredients, \% & \\
Rolled corn & 70.0 \\
Corn DDG & 15.0 \\
Alfalfa hay chopped at 3-5 cm & 10.0 \\
Soybean meal 44\% CP & 2.40 \\
Calcium carbonate & 1.00 \\
Bicalcium phosphate & 0.40 \\
Sodium bicarbonate & 0.40 \\
Urea & 0.30 \\
Salt & 0.30 \\
Vitamin-mineral premix 1 & 0.20 \\
Nutrients, \% DM basis & \\
ME, Mcal/kg & 3.19 \\
CP, \% & 16.7 \\
Ether extract, \% & 6.2 \\
NDF. \% & 21.6 \\
Starch, \% & 48.0 \\
Ash & 5.1 \\
Calculated non-structural carbohydrate & 50.4
\end{tabular}

${ }^{1}$ Nucleous for finisher concentrate (CAG, Guissona, Spain): vitamin and mineral contained per kg of DM: $3575.8 \mathrm{kIU}$ of vitamin $\mathrm{A}, 858.6 \mathrm{kIU}$ of vitamin $\mathrm{D}_{3}, 101 \mathrm{~g}$ of vitamin $\mathrm{E}, 2.3 \mathrm{~g}$ of vitamin $\mathrm{B}_{1}, 0.2 \mathrm{~g}$ of $\mathrm{Co}, 2.5 \mathrm{~g}$ of Cu, $0.26 \mathrm{~g}$ of I, $15.7 \mathrm{~g}$ of $\mathrm{Mn}, 0.15 \mathrm{~g}$ of Se, $20.6 \mathrm{~g}$ of $\mathrm{Zn}, 7.2 \mathrm{~g}$ of Fe, $75.8 \mathrm{~g}$ of etoxiquine and $1 \mathrm{~kg}$ of barley as excipient. 3. Metabolizable energy(ME).

\subsection{Measurements and Sample Collection}

Health status (presence of coughing, visible discharge in nose or eyes, droopy ears, head tilt, diarrhea, bloat and fever) was recorded daily. 


\subsubsection{Feed Consumption}

Feed offers (concentrate and straw or TMR) were recorded daily at 9:00 a.m., and feed leftovers were registered daily at 8:00 a.m. Animal BW was recorded every two weeks at the beginning of each period.

\subsubsection{Apparent Total Tract Digestibility and D-lactate Concentration in Feces}

Two criteria were chosen to determine the suitable duration of the experimental period (14 days). First, it should be sufficient to avoid carry-over effects from previous treatments (washout). Second, this period should be as short as possible to reduce the risk that the animals may drastically change their rumen fermentation, metabolism and intake during the study because these animals were still growing. Considering that the basal-high-concentrate diet remained unchanged during the entire study and that research indicates that ruminant total tract digestibility ordinarily adjusts to diet within 10 to $14 \mathrm{~d}$ when high concentrate $\operatorname{diet}(>50 \%)$ is fed $[15,16]$, the adaptation period was set at 12 days for the current study. From day 8 to 14 chromium oxide $(1 \mathrm{~g} / \mathrm{kg} \mathrm{DM})$ was added to the TMR as an indigestible marker for nutrient digestibility determination. During these days a sample of feed offer (concentrate and mixed ration) and refusals from each animal were collected. Fecal grab samples were collected from day 12 to 14 from the rectum and dried at $55^{\circ} \mathrm{C}$ for $48 \mathrm{~h}$, and composited by animal and period on an equal DM basis.

\subsubsection{Chemical Analyses}

Feed samples of each dietary treatment were collected every 2 weeks for determination of nutrient composition. Samples were analyzed for DM (24 h at $103{ }^{\circ} \mathrm{C}$; method number 925.04; [17]), ash (4 h at $550^{\circ} \mathrm{C}$; method number 642.05 ; [17]), CP by the Kjeldahl method (method number 988.05; [17]), NDF according to Van Soest et al. [18] using sodium sulfite and AA and fat using a Soxhlet apparatus after an acid hydrolysis preparation [17]. Total starch content was analyzed using the polarimetric method according to the EU Regulation for feed analyses ( $n^{\circ}$ 152/2009). Chromium concentration of feed and fecal samples were determined based on the procedure of Le Du and Penning [19]. Digestion was carried out on duplicates weighing $0.5 \mathrm{~g}$ of sample. Two digestion steps were made. The first digestion step was performed with $4 \mathrm{~mL} \mathrm{HNO}_{3}(65 \%, w / w)$ concentrated at $220^{\circ}$ during $15 \mathrm{~min}$, in a microwave oven (Ultrawave model, Milestone, Sorisole, Italy); uncolored solutions were obtained with a green solid at the bottom of the digestion tube. That solid is attributed to $\mathrm{Cr}_{2} \mathrm{O}_{3}(\mathrm{~s})$. In the second step, $3 \mathrm{~mL}$ of $\mathrm{H}_{2} \mathrm{SO}_{4}(95-97 \%, w / w), 0.5 \mathrm{~mL}$ of $\mathrm{HClO}_{4}(32 \%, w / w)$ and $2 \mathrm{~mL}$ of hydrofluoric acid $(40 \%, w / w)$ at the same digestion tube were added and new a digestion procedure was made at $260{ }^{\circ} \mathrm{C}$ for $15 \mathrm{~min}$. Finally, the $\mathrm{Cr}$ content was determined by inductively coupled plasma optical emission spectrometry (model Optima 4300D, Perking-Elmer, Shelton, CT, USA).

$D$-lactate concentration in deproteinized feces was analyzed by an enzymatic-fluorometric method, according to Larsen [20]. Dried feces (200 mg) were extracted for $2 \mathrm{~h}$ in $2.00 \mathrm{~mL} 66 \%$ (V/V) ethanol, at room temperature with periodic vibrations on a whirl mixer. Samples were centrifuged for $10 \mathrm{~min}$ $(3500 \times g)$ and supernatants obtained were used for analyses after diluted with $66 \%$ ethanol.

\subsection{Calculations and Statistical Analyses}

Apparent total tract digestibility was calculated estimating total fecal output, which was estimated as the ratio of chromium intake to chromium concentration in the feces.

Data were analyzed using a mixed-effects model (Version 9.2, SAS Inst., Inc., Cary, NC, USA). The model included initial BW as a covariate, treatment, period (14 d period), as fixed effects, and block and animal nested within block as random effect. Differences between treatments were compared using the PDIFF option in the LSMEANS statement. For all analyses, significance was declared at $p \leq 0.05$ and tendencies were discussed at $0.05<p \leq 0.10$. 


\section{Results and Discussion}

Throughout the study, there were no health incidences recorded and treatment did not affect total feed intake (Table 2). Apparent total tract digestibility values were slightly lower than, but still within, the observed range when bulls are fed high-concentrate diets rich in rolled corn [21,22].

Table 2. Daily nutrient intake, nutrient fecal output and apparent total tract digestibility in crossbred Angus bulls fed TMR supplemented with the different enzymes (TrGA = Trichoderma reesei glucoamylase; AfuGA = Aspergillus fumigatus glucoamylase; AfuGABamPro = Aspergillus fumigatus Glucoamylase + Bacillus amyloliquefaciens neutral protease).

\begin{tabular}{|c|c|c|c|c|c|c|}
\hline \multicolumn{7}{|c|}{ Treatment ${ }^{1}$} \\
\hline & CTR & TrGA & AfuGA & AfuGA + BamPro & SEM & $p$-Value ${ }^{2}$ \\
\hline \multicolumn{7}{|l|}{ Intake, $\mathrm{kg} / \mathrm{d}$} \\
\hline $\mathrm{DM}$ & 7.8 & 7.9 & 8.0 & 7.6 & 0.12 & 0.19 \\
\hline $\mathrm{OM}$ & 7.4 & 7.5 & 7.6 & 7.3 & 0.12 & 0.18 \\
\hline Starch & 3.7 & 3.8 & 3.8 & 3.7 & 0.07 & 0.29 \\
\hline $\mathrm{CP}$ & 1.3 & 1.3 & 1.3 & 1.2 & 0.03 & 0.11 \\
\hline Ether extract & 0.49 & 0.49 & 0.49 & 0.46 & 0.009 & 0.10 \\
\hline NDF & 1.7 & 1.7 & 1.7 & 1.7 & 0.03 & 0.33 \\
\hline \multicolumn{7}{|c|}{ Fecal output, kg/d } \\
\hline DM & 2.5 & 2.3 & 2.0 & 2.1 & 0.16 & 0.15 \\
\hline $\mathrm{OM}$ & 2.4 & 2.1 & 1,9 & 1.9 & 0.16 & 0.15 \\
\hline Starch & 0.93 & 0.76 & 0.61 & 0.69 & 0.088 & 0.07 \\
\hline $\mathrm{CP}$ & 0.40 & 0.37 & 0.35 & 0.35 & 0.027 & 0.45 \\
\hline Ether extract & 0.18 & 0.18 & 0.17 & 0.17 & 0.013 & 0.86 \\
\hline NDF & 0.79 & 0.76 & 0.72 & 0.71 & 0.050 & 0.61 \\
\hline \multicolumn{7}{|c|}{ Apparent total tract digestibility, $\%$} \\
\hline $\mathrm{DM}$ & $66.7^{\mathrm{b}}$ & $71.1^{\mathrm{a}}$ & $74.7^{\mathrm{a}}$ & $72.8^{\mathrm{a}}$ & 2.01 & 0.05 \\
\hline $\mathrm{OM}$ & $66.8^{\mathrm{b}}$ & $71.3^{\mathrm{a}}$ & $74.9^{\mathrm{a}}$ & $72.9^{\mathrm{a}}$ & 2.03 & 0.05 \\
\hline Starch & $74.7^{\mathrm{b}}$ & $80.2^{\mathrm{a}}$ & $84.1^{\mathrm{a}}$ & $81.3^{\mathrm{a}}$ & 2.25 & 0.04 \\
\hline $\mathrm{CP}$ & 67.7 & 70.8 & 74.4 & 72.4 & 2.14 & 0.17 \\
\hline Ether extract & 61.2 & 62.5 & 64.7 & 62.7 & 2.87 & 0.84 \\
\hline NDF & 50.0 & 53.9 & 58.4 & 58.1 & 2.91 & 0.15 \\
\hline
\end{tabular}

$1 \overline{\mathrm{CTR}}=$ no supplementation, only preservatives, TrGA $=$ Trichoderma reesei glucoamylase; AfuGA $=$ Aspergillus fumigatus glucoamylase; AfuGABamPro = Aspergillus fumigatus glucoamylase + Bacillus amyloliquefaciens neutral protease). a,b Within a row means with different superscripts are statistically different $(p<0.05)$. ${ }^{2}$ Treatment effect. organic matter $(\mathrm{OM})$.

The current study is the first attempt to evaluate GA, alone or in combination with protease on starch digestibility in large ruminants. Glucoamylases were selected in this study considering rumen microbiota metagenome data available in recent years showing more abundancy of AA genes than GA genes [5,6]. In the current study, TrGA and AfuGA significantly improved apparent total tract starch digestibility by 7 and 13\%, respectively, as compared with control CTR $(p<0.05)$. Rojo et al. [23] reported in lambs that feeding sorghum grain with GA from $A$. niger did not affect ruminal or total tract starch digestion but resulted in higher partial feed efficiency. Mota et al. [24] supplemented the same GA to lambs fed corn-based high concentrate diets and found significant improvement in feed conversion ratio (12\%) as compared with those fed a non-enzyme control diet, with similar average daily gain. It is not easy to attribute the exact cause(s) for observing different responses between lamb and cattle (current study), but feeding frequency, animals' physiological status and enzyme inclusion ratio, application method, impurities in the enzyme mixture, degree of grain processing, etc., could be part of the explanation [25-27].

Contrary to our hypothesis [26,28], supplementing GA with protease showed no synergic effect on any of the parameters tested. Several studies have reported the effects of various proteases on digestibility in ruminants. In dairy cows, Eun and Beauchemin [29] studied the effects of exogenous 
proteolytic enzymes (serine protease type) in lactating Holstein cows fed high or low forage diets and observed an increased starch digestibility in enzyme-supplemented treatments when cows were fed high-forage diets. In growing beef cattle [11], the addition of an experimental exogenous proteolytic enzyme increased DMI of steers by $14.8 \%$, but reduced NDF digestibility $(4.1 \%)$, but no impact on performance (weight gain or feed efficiency). In finishing cattle, no effects were observed on digestibility or performance when the same enzyme was supplemented [11].

$D$-lactate is of microbial origin and not produced by mammalian cells. $D$-Lactate concentration in feces is a resulting product of fermentation of carbohydrates in the intestine, particularly the large intestine [12]. Therefore, decreased $D$-lactate concentrations in feces could be an indicator of improved overall starch digestion in the digestive tract. In feedlot cattle, decreasing feces $D$-lactate and fecal starch content may decrease the risk of hind-gut acidosis. Therefore, exogenous enzymes could also improve animal performance by not only enhancing ruminal carbohydrate degradability but also postruminal nutrient absorption and fermentation [30]. In the present study, feces $D$-lactate concentration followed a similar pattern to feces starch daily excretion (Figure 1), even though the results were not significant $(p=0.29)$.

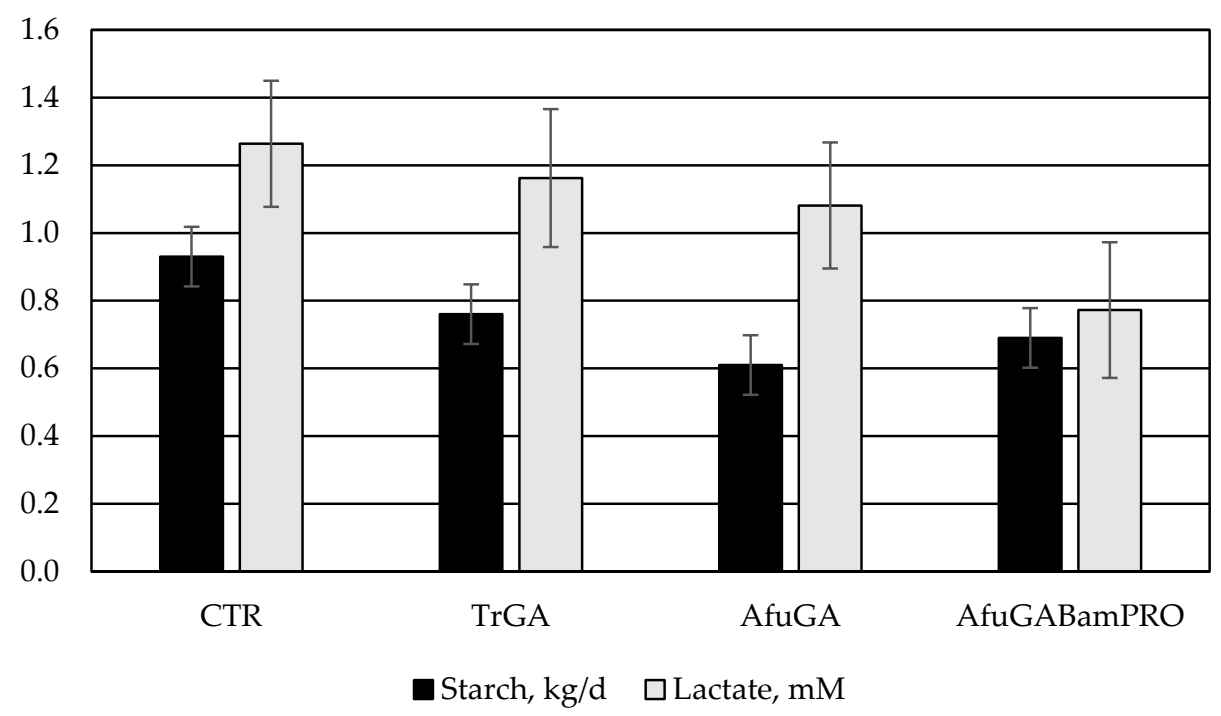

Figure 1. Daily fecal starch output $(\mathrm{kg} / \mathrm{d})$ and fecal $D$-lactate concentration $(\mathrm{mM})$ in crossbred Angus bulls fed TMR supplemented with the different enzymes (TrGA = Trichoderma reesei glucoamylase; AfuGA = Aspergillus fumigatus glucoamylase; AfuGABamPro = Aspergillus fumigatus glucoamylase + Bacillus amyloliquefaciens neutral protease).

\section{Conclusions}

In summary, in crossbred Angus fed over $70 \%$ of rolled corn, apparent total tract starch digestibility was significantly increased when supplementing a fungal glucoamylase from T. reesei or A. fumigatus or a mixture of the A. fumigatus glucoamylase and a neutral protease from B. amyloliquefaciens.

Author Contributions: Contributions for this short communication are: conceptualization, M.D., L.W.; methodology, M.D., L.W., S.Y., T.L.; formal analysis, M.D., S.G.; investigation, M.D., S.G.; writing-original draft preparation, M.D.; writing-review and editing, M.D., S.Y., S.G., T.L., L.W.; supervision, M.D., L.W., S.G.; project administration, M.D., L.W.; funding acquisition, L.W. All authors have read and agreed to the published version of the manuscript.

Funding: This research was founded by Dupont Animal Nutrition, Wilmington, DE 19803, USA.

Acknowledgments: This study was performed on the experimental farm from bonÀrea Agrupa. The authors thank the farm workers for their collaboration. IRTA also thanks the support of the Generalitat de Catalunya through the CERCA Programme. 
Conflicts of Interest: M. Devant, S. Genis and T. Larsen declare no conflict of interest. The funders, L. Wenting and S. Yu, had no role in the collection, analyses or interpretation of data, but they had a role in study design, writing of the manuscript (review) and decision to publish the results.

\section{References}

1. Owens, F.N.; Secrist, D.S.; Hill, W.J.; Gill, D.R. The Effect of Grain Source and Grain Processing Performance of Feedlot Cattle: A Review. J. Anim. Sci. 1997, 75, 868-879. [CrossRef] [PubMed]

2. Drouillard, J.S. Current situation and future trends for beef production in the United States of America-A review. Asian Australas. J. Anim. Sci. 2018, 31, 1007-1016. [CrossRef] [PubMed]

3. Huntington, G.B. Starch utilization by ruminants: From basics to the bunk. J. Anim. Sci. 1997, 75, 852-867. [CrossRef] [PubMed]

4. Owens, F.N.; Zinn, R.A. Corn grain for cattle: Influence of processing on site and extent of digestion. Southwest Nutr. Conf. Univ. Arizona. 2005, 78-85. Available online: http://animal.cals.arizona.edu/swnmc/ 2005/index.htm (accessed on 21 June 2020).

5. Stewart, R.D.; Auffret, M.D.; Warr, A.; Wiser, A.H.; Press, M.O.; Langford, K.W.; Liachko, I.; Snelling, T.J.; Dewhurst, R.J.; Walker, A.W.; et al. Assembly of 913 microbial genomes from metagenomic sequencing of the cow rumen. Nat. Commun. 2018, 9, 870. [CrossRef]

6. Wang, L.; Zhang, G.; Xu, H.; Xin, H.; Zhang, Y. Metagenomic analyses of microbial and carbohydrate-active enzymes in the rumen of Holstein cows fed different forage-to-concentrate ratios. Front. Microbiol. 2019, 10, 1-4. [CrossRef]

7. Yu, S.; Kragh, K.M.; Li, W. Use of low $\mathrm{pH}$ active alpha-1,4/1,6-glycoside hydrolases as a feed additive for ruminants to enhance starch digestion. WO 2018/057420 A1. 2018. Available online: https://worldwide.espacenet.com/publicationDetails/biblio?DB=EPODOC\&II=4\&ND=4\&adjacent= true\&locale=en_EP\&FT $=$ D\&date $=20190829 \& C C=W O \& N R=2018057420 A 1 \& K C=A$ (accessed on 21 June 2020).

8. Shaw, A.; Wallace, L.; Estell DA Hommes RW, J.; Lee, S.; Oh, H.; Sadlowski, E.S. Thermostable Neutral Metalloproteases. U.S. Patent US 8574884 B2, 5 November 2013.

9. McAllister, T.A.; Ribeiro, G. Microbial strategies in the ruminal digestion of starch. In Proceedings of the 50th Annual Meeting Brazilian Society Animal Science, Campinas, Brazil, 23 July 2013; pp. 140-151.

10. DiLorenzo, N.; Smith, D.R.; Quinn, M.J.; May, M.L.; Ponce, C.H.; Steinberg, W.; Engstrom, M.A.; Galyean, M.L. Effects of grain processing and supplementation with exogenous amylase on nutrient digestibility in feedlot diets. Livest. Sci. 2011, 137, 178-184. [CrossRef]

11. Vera, J.M.; Smith, H.; ZoBell, D.R.; Young, A.J.; Eun, J.S. Effects of an exogenous proteolytic enzyme on growth performance of beef steers and in vitro ruminal fermentation in continuous cultures. Prof. Anim. Sci. 2012, 28, 452-463. [CrossRef]

12. Christopher, M.M.; Broussard, J.D.; Fallin, C.W.; Drost, N.J.; Peterson, M.E. Increased serum D-lactate associated with diabetic ketoacidosis. Metabolism 1995, 44, 287-290. [CrossRef]

13. Del Estado, B.O. Royal Decree 53/2013 of February 1st on the protection of animals used for experimentation or other scientific purposes. Boletín Oficial del Estado 2013, 34, 11370-11421.

14. NRC. Nutrient Requirements of Beef Cattle, 7th ed.; National Academies Press: Washington, DC, USA, 2000.

15. Grant, R.J.; Dann, H.M.; Woolpert, M.E. Time required for adaptation of behavior, feed intake and dietary digestibility in cattle. J. Anim. Sci. 2015, 93 (Suppl. 3), 312.

16. Machado, M.; Detmann, G.E.; Mantovani, H.C.; Valadares Filho, S.C.; Bento CB, P.; Marcondes, M.I.; Assunçao, A.S. Evaluation of the length of adaptation period for changeover and crossover nutritional experiments with cattle fed tropical forage-based diets. Anim. Feed Sci. Technol. 2016, 222, 132-148. [CrossRef]

17. AOAC. Official Methods of Analysis, 16th ed.; Official Methods of Analysis: Arlington, VA, USA, 1995.

18. Van Soest, P.J.; Robertson, J.B.; Lewis, B.A. Methods for dietary fiber, neutral detergent fiber, and nonstarch polysaccharides in relation to animal nutrition. J. Dairy Sci. 1991, 74, 3583-3597. Available online: http://linkinghub.elsevier.com/retrieve/pii/S0022030291785512 (accessed on 21 June 2020). [CrossRef]

19. Le Du, Y.L.P.; Penning, P.D. Animal based techniques for estimating herbage intake. In Herbage Intake Handbook; Leaver, J.D., Ed.; Grassland Res. Inst.: Hurley, UK, 1982; pp. 37-75.

20. Larsen, T. Fluorometric determination of D-Lactate in biological fluids. Anal. Biochem. 2017, 539, $152-157$. 
21. Zinn, R.A.; Adam, C.F.; Tamayo, M.S. Interaction of feed intake level on comparative ruminal and total tract digestion of dry-rolled and steam-flaked corn. J. Anim. Sci. 1995, 73, 1239-1245. [CrossRef] [PubMed]

22. Owens, C.E.; Zinn, R.A.; Hassen, A.; Owens, N. Mathematical linkage of total tract digestion of starch and neutral detergent fiber to their fecal concentrations and the effect of site of starch digestion on extent of digestion and energetic efficiency of cattle. Profess. Anim. Sci. 2016, 32, 531-549. [CrossRef]

23. Rojo, R.; Mendoza, G.D.; González, S.; Landois, L.; Bárcena, R.; Crosby, M.M. Effects of exogenous amylases from Bacillus licheniformis and Aspergillus niger on ruminal starch digestion and lamb performance. Anim. Feed Sci. Technol. 2005, 123, 655-665. [CrossRef]

24. Mota, N.; Mendoza, G.D.; Plata, F.X.; Martínez, J.A.; Lee, H.; Rojo, R.; Crosby, M.M. Effect of exogenous glucoamylase enzymes and reduction of grain level on lamb performance. J. Appl. Anim. Res. 2011, 39, 129-131. [CrossRef]

25. Meale, S.J.; Beauchemin, K.A.; Hristov, A.N.; Chaves, A.V.; McAllister, T.A. Opportunities and challenges in using exogenous enzymes to improve ruminant production. J. Anim. Sci. 2014, 92, 427-442. [CrossRef]

26. McAllister, T.A.; Cheng, K.J. Microbial strategies in the ruminal digestion of cereal grains. Anim. Feed Sci. Technol. 1996, 62, 29-36. [CrossRef]

27. Grifé, L.; Arís, A.; Bach, A.; García-Fruitós, E. Trends in recombinant protein use in animal production. Microbial Cell Factories 2017, 16, 40.

28. Amaro, F.X.; Arriola, K.G.; Kim, D.; Fernandes, T.; Agarussi, M.C.N.; Silva, V.P.; Cervantes, A.P.; Jiang, Y.; Ferraretto, L.F.; Vyas, D.; et al. The effects of adding exogenous amylases and proteases on ruminal in vitro dry matter and starch digestibility of dent corn grain. J. Dairy Sci. 2018, 101 (Suppl. 2), 356.

29. Eun, J.S.; Beauchemin, K.A. Effects of proteolytic feed enzyme on intake, digestion, ruminal fermentation, and milk production. J. Dairy Sci. 2005, 88, 2140-2153. [CrossRef]

30. Hristov, A.N.; McAllister, T.A.; Cheng, K.J. Intraruminal supplementation with increasing levels of exogenous polysaccharide-degrading enzymes: Effects on nutrient digestion in cattle fed a barley grain diet. J. Anim. Sci. 2000, 78, 477-487. [CrossRef]

(C) 2020 by the authors. Licensee MDPI, Basel, Switzerland. This article is an open access article distributed under the terms and conditions of the Creative Commons Attribution (CC BY) license (http://creativecommons.org/licenses/by/4.0/). 